\title{
Recent Ice-Sheet Growth in the Interior of Greenland
}

Ola M. Johannessen, ${ }^{1,2^{*}}$ Kirill Khvorostovsky, ${ }^{3}$ Martin W. Miles, ${ }^{4,5}$ Leonid P. Bobylev ${ }^{3}$

${ }^{1}$ Mohn-Sverdrup Center for Global Ocean Studies and Operational Oceanography / Nansen Environmental and Remote Sensing Center, Bergen, 5006, Norway. ${ }^{2}$ Geophysical Institute, University of Bergen, 5007, Norway. ${ }^{3}$ Nansen International Environmental and Remote Sensing Center, St. Petersburg, 197101, Russia. ${ }^{4}$ Bjerknes Centre for Climate Research, Bergen, 5007, Norway. ${ }^{5}$ Environmental Systems Analysis Research Center, Boulder, CO 80303, USA.

*To whom correspondence should be addressed. E-mail: ola.johannessen@nersc.no

A continuous data set of Greenland Ice Sheet altimeter height from ERS-1 and ERS-2 satellites, 1992 to 2003, has been analyzed. An increase of $6.4 \pm 0.2$ centimeters per year is found in the vast interior areas above 1500 meters, in contrast to previous reports of high-elevation balance. Below 1500 meters, the elevation-change rate is $-2.0 \pm 0.9$ $\mathrm{cm} /$ year, in qualitative agreement with reported thinning in the ice-sheet margins. The spatially averaged increase is $5.4 \pm 0.2 \mathrm{~cm} /$ year, or $\sim 60 \mathrm{~cm}$ over 11 years, or $\sim 54 \mathrm{~cm}$ when corrected for isostatic uplift. Winter elevation changes are shown to be linked to the North Atlantic Oscillation.

The Greenland Ice Sheet is an object of increased attention for at least two reasons related to global climate change $(1,2)$. First, complete melting of the ice sheet would raise the global sea level up to 7 meters. This process, expected to occur on a millennial time scale, should begin when the critical $\sim 3^{\circ} \mathrm{C}$ threshold for Greenland climate warming is crossed, perhaps before the end of this century $(2,3)$. Second, increased Greenland Ice Sheet melt and freshwater input into the northern North Atlantic Ocean have been theorized to weaken or even disrupt the global thermohaline circulation on a relatively rapid, multidecadal time scale $(4,5)$. Here, we address changes in the surface elevation of the interior of the Greenland Ice Sheet, which is pertinent to both of these critical issues through glacier mass balance, i.e., accumulation minus losses.

The response of the Greenland Ice Sheet to climate forcing is not straightforward, as variability in solar radiation, greenhouse gases (GHGs), atmospheric circulation, surface temperature, cloud cover, precipitation and albedo, as well as glacier-flow dynamics, may affect the magnitude, rate and direction of changes in glacier mass balance (1-3, 6). Efforts to measure changes in the Greenland Ice Sheet from field observations and aerial and satellite remote sensors have improved our knowledge over the past decade, although there is yet no consensus assessment of the overall mass balance of the ice sheet (6). There is nonetheless considerable evidence of melting $(7-9)$ and thinning $(10,11)$ in the coastal marginal areas in recent years, as well as indications that large Greenland outlet glaciers can surge at subdecadal time scales (12), possibly in response to climate. Less known are changes that may be occurring in the vast elevated interior area of the ice sheet, although a balance has been reported based on some tracks of aerial laser altimetry, unevenly sampled in space and time $(10,13)$. This underscores the need for long, continuously sampled data sets, such as derived from satellite altimetry. Whereas decadal and longer satellite-derived data sets have been developed for surface melt (7-9), the surfaceelevation data sets analyzed previously have been discontinuous $(10,11,13)$ and relatively short (14). Therefore we derive and analyze a continuous satellitealtimeter height record of Greenland Ice Sheet elevations by combining European Space Agency ERS-1 and ERS-2 data, in order to (i) determine the spatial patterns of surface elevation changes over an 11-year period, 1992-2003, (ii) determine seasonal and interannual variability of the surface elevation over the same period, and (iii) investigate how observed elevation changes are linked to the North Atlantic Oscillation (NAO) pattern of atmospheric circulation (15), which we hypothesize to have an underappreciated role on the Greenland Ice Sheet surface elevation through its effect on winter precipitation. This is a critical issue, as the NAO index (16) is predicted to become more positive in response to increasing GHGs $(17,18)$.

The data set analyzed here to identify Greenland Ice Sheet surface-elevation changes is based on 11 consecutive years of ERS-1 and ERS-2 radar altimeter height measurements (19). The methodology used to calculate elevation changes is based on the crossover analysis using the differences in ice-mode altimeter heights at crossing points of the satellite-orbit ground tracks (19). Elevation change rates $(d H / d t)$ were calculated for $0.5^{\circ}$ latitude $\times 1.0^{\circ}$ longitude cells using two methods. In the first method—-the $d H / d t$ method (20) — we used all available crossovers. The $d H / d t$ was determined as a slope of a linear fit to the crossover difference of elevations 
versus time interval using descending minus ascending orbits. The second method — the time series method (21) — was applied to form seasonally averaged time series of elevation change, using descending minus ascending orbits and ascending minus descending orbits (19). Thus, the first method gives the spatial elevation change averaged for the entire time interval, while the second method allows investigation of the temporal variability of spatial averages.

However, in order to merge ERS-1 and ERS-2 as one data set, it is essential to account for bias between the satellites. To achieve this, we developed and applied the following procedures. First, we applied the systematic $40.9 \mathrm{~cm}$ offset, with ERS-2 being lower then ERS-1, specified by ESA (22) and confirmed by (23) before investigating the remaining bias. Although there was a year (1995-1996) when the satellites operated in tandem, the number of ERS-1/ERS-2 crossover points available during this period is considered insufficient to determine the between-satellite bias directly from elevation differences during the overlap (19). Therefore, we estimated the bias using a large number (8 million) of crossover points between ERS-1 orbits during its whole period of operation from 1992-1996 and ERS-2 ones from a period of equal length, 1995-1999, including the 1-year overlap, giving higher reliability (19 and fig. S1). The calculated spatially averaged ERS-1/ERS-2 bias is $21.5 \pm 2.0$ $\mathrm{cm}$. The bias is spatially variable and the effect of the bias on determining $d H / d t$ from the used crossover data varies from typically $\sim 2 \mathrm{~cm} /$ year over the interior plateau to about 20 $\mathrm{cm}$ /year over ice-sheet margins (19). We applied this bias for each ERS-1 $\times$ ERS-2 crossover point, before calculating the $d H / d t$ average for each cell.

The spatial pattern of variability derived from the $d H / d t$ method is mapped as 11-year elevation-change rate for each cell (Fig. 1), based on 45 million crossover points distributed over three data sets: ERS-1 (ERS-1 $\times$ ERS-1), ERS-2 (ERS-2 $\times$ ERS-2) and ERS-1 and ERS-2 (ERS-1 $\times$ ERS-2). Positive $d H / d t$ values are generally found over most of the highelevation areas, with largest positive values of up to 10-20 $\mathrm{cm} /$ year in southwestern $\left(<69^{\circ} \mathrm{N}\right)$ and eastern Greenland between $74-77^{\circ} \mathrm{N}$. The largest negative values, -25 to -30 $\mathrm{cm} /$ year, are found in several parts of western Greenland, where independent aerial altimetry in 1997 and 2002/2003 also found the greatest thinning (11). Negative values are also found in southeastern Greenland $\left(63-66^{\circ} \mathrm{N}\right)$ and in the northeastern ice stream $\left(78-80^{\circ} \mathrm{N}\right)$, with values of -10 to -15 $\mathrm{cm} /$ year. The regional differences in elevation change reflect, to a varying degree, the location of ice divides (Fig. 1), notably between southwest and southeast Greenland, +10 to $+20 \mathrm{~cm} /$ year and -5 to $-15 \mathrm{~cm} /$ year, respectively. Most of the significant thinning is observed over outlet glacier areas, particularly in western, southeastern and northeastern
Greenland, implying a dynamic mechanism in addition to changes in precipitation and melting (e.g., 24, 25).

The surface-elevation change rate averaged over the Greenland Ice Sheet (excluding those marginal cells with unreliable data (19)) is $+5.4 \pm 0.2 \mathrm{~cm} /$ year, or $\sim 60 \mathrm{~cm}$ for the period 1992-2003. We have partitioned the variability into different elevation bands of 500 m intervals, starting at $<1500$ $\mathrm{m}$ and extending to $>3000 \mathrm{~m}$ (Table 1). Below $1500 \mathrm{~m}$, where summer melting is pronounced, the mean $d H / d t$ is $-2.0 \pm 0.9$ $\mathrm{cm} /$ year for the period 1992-2003. Above $1500 \mathrm{~m}$, the mean $d H / d t$ is $+6.4 \pm 0.2 \mathrm{~cm} /$ year. These $d H / d t$ values are before correcting for isostatic uplift, which is estimated to be approximately $0.5 \mathrm{~cm} /$ year averaged for the entire Greenland Ice Sheet (26). When adjusted for average uplift, the overall ice thickness changes are thus approximately $+5 \mathrm{~cm} /$ year or $54 \mathrm{~cm}$ over 11 years, while above $1500 \mathrm{~m}$, these values are approximately $+6 \mathrm{~cm} /$ year or $65 \mathrm{~cm}$ over 11 years. The latter results are in contrast to the high-elevation balance reported previously $(10,13)$ based on spatially and temporally discontinuous observations, in contrast to our 11-year data set comprising 45 million crossover points. The positive changes observed here imply increased accumulation, supported by evidence that elevation changes in the interior of Greenland can be attributed primarily to snow accumulation (27).

The time-series analysis (19) of elevation changes spatially averaged over all cells $<1500 \mathrm{~m}$ and $>1500 \mathrm{~m}$ indicates seasonal and interannual variability of up to tens of $\mathrm{cm}$ (Fig. 2). Below $1500 \mathrm{~m}$, there is no significant trend until 1999, after which a negative trend of $\sim 6 \mathrm{~cm} /$ year is evident. Above $1500 \mathrm{~m}$, the positive change is $6.1 \pm 0.6 \mathrm{~cm} /$ year, confirming the result from the $d H / d t$ method. The overall elevation change derived from the time-series method is $+5.3 \pm 0.5$ $\mathrm{cm} /$ year, also confirming the $d H / d t$ result.

Regional temperature and precipitation are both influenced by the NAO (15). Since the NAO in winter strongly affects precipitation, with $r \sim-0.75$ for model-calculated total Greenland precipitation for Greenland and $r \sim-0.80$ for southern Greenland (28), we hypothesized that the NAO weather and precipitation pattern strongly affects ice-sheet elevation change. However, systematic precipitation measurements are available almost exclusively for the coastal stations and not the interior, such that the NAO index may serve as a proxy for precipitation. Therefore, we examine the direct relationship between Greenland Ice Sheet elevation change and the NAO index (16). Elevation changes during winter have been calculated from the time series using the differences between winter (DJF) and the preceding autumn (SON). Fig. 3 shows ice-sheet elevation changes during winter and the winter NAO index, 1992-2003. The correlation between elevation changes and the NAO is maximum when lagged one month, e.g., NDJ for the NAO and DJF for elevation, with $r \sim-0.88(s<0.05, d f=10)$ thus 
explaining about three quarters $\left(r^{2} \sim 0.77\right)$ of the elevation changes. The correlations for spring, summer and autumn are, as expected, lower: $0.04,-0.08$, and -0.28 , respectively, implying no significant effect of the NAO during these seasons. The winter correlation $(-0.88)$ is stronger than the above-mentioned correlations for the NAO and modeled Greenland precipitation (28), implying that the NAO index is a very good proxy for winter precipitation data. Therefore, strongly negative NAO-index conditions lead to increased accumulation and elevation change during wintertime and vice versa. This is exemplified by the changes observed from 1994/1995 $(-10.1 \mathrm{~cm})$ to 1995/1996 (+11.6 cm), associated with a record positive-to-negative NAO reversal (2.4 $\sigma$ to $3.1 \sigma$ ) (Fig. 3).

The relationship is based not only on the intensity of the NAO, but also on the development and position of the Icelandic Low (29), which, e.g., between 1994/1995 and 1995/1996 shifted southwestward to Cape Farewell (Fig. 4), giving higher precipitation especially in southern Greenland. However, in other years, a weak negative NAO index may be due simply to a weakly developed Icelandic Low, in which case the elevation change is barely positive, as in 2001 (Fig. 3 ). The relationship appears weak in the most recent years, from 2001, with the NAO index relatively neutral.

The observed correlation between the NAO and ice-sheet elevation changes suggests that future trends in the NAO could influence the Greenland Ice Sheet surface elevation. The winter NAO index trend has been generally positive since the 1960s, though during our 1992-2003 study period, the trend happened to be slightly negative, hence the observed increase in elevation. Model experiments with increasing atmospheric concentrations of GHGs generally indicate an increasing (positive) NAO and a slight northeastward displacement of the Icelandic Low in the future $(17,18)$ both implying less winter accumulation over Greenland.

Nonetheless, as mentioned, the NAO can explain about three quarters of the surface elevation changes, leaving us to speculate on other factors. A modeling study (30) of the Greenland Ice Sheet mass balance under greenhouse global warming has shown that temperature increases up to $2.7^{\circ} \mathrm{C}$ lead to positive mass balance changes at high elevations (due to accumulation) and negative at low elevations (due to runoff exceeding accumulation), consistent with our findings, implying that perhaps a quarter of the growth may be caused by global warming in Greenland (31) in our observation period. Furthermore, the observed elevation change implies that ice-sheet growth in the interior of Greenland may partly offset the freshwater flow of the retreating subpolar glaciers needed to explain the freshening rate of the world ocean, which can be explained almost entirely by arctic sea-ice melt (32).
In conclusion, we have presented new evidence of (i) decadal increase in Greenland Ice Sheet surface elevation ( 5 cm/year), 1992-2003, caused by accumulation over extensive areas in the interior of Greenland; (ii) divergence in elevation changes since the year 2000 for areas above and below 1500 $\mathrm{m}$, with high-elevation increases and low-elevation decreases, the former in contrast to previous research $(10,13)$; and (iii) negative correlation between winter elevation changes and the NAO index, suggesting an underappreciated role of the winter season and the NAO for elevation changes - a wildcard in Greenland Ice Sheet mass-balance scenarios under global warming.

There are, however, caveats to consider. First, we cannot make an integrated assessment of elevation changes-let alone ice volume and its equivalent sea-level change-for the whole Greenland Ice Sheet including its outlet glaciers from these observations alone, as the marginal areas are not measured completely using ERS-1/ERS-2 altimetry (see Fig. 1). It is conceivable that pronounced ablation (e.g., 10,11) in low-elevation marginal areas could offset the elevation increases that we observed in the interior areas. Second, there is large interannual to decadal variability in the high-latitude climate system including the NAO, such that the 11-year long data set developed here remains too brief to establish longterm trends. Therefore, there is clearly a need for continued monitoring using new satellite altimeters-including advanced ones with improved ice-sheet ranging in steeper coastal areas - and other remote-sensing and field observations, together with numerical modeling to calculate the mass budget through net losses and net input from snow (33).

\section{References and Notes}

1. Intergovernmental Panel on Climate Change (IPCC), Climate Change 2000: Third Assessment Report (Cambridge Univ. Press, Cambridge, 2001).

2. Arctic Climate Impact Assessment (ACIA) Impacts of a Warming Arctic (Cambridge Univ. Press, Cambridge, 2004).

3. J. M. Gregory, P. Huybrechts, S. C. B. Raper, Nature 428, 616 (2004).

4. S. Ramstorf, Clim. Change 46, 247 (2000).

5. T. Fichefet et al., Geophys. Res. Lett. 30 1911, doi:10.1029/2003GL017826 (2003).

6. E. Rignot, R. H. Thomas, Science 297, 1502 (2002).

7. W. Abdulati et al., J. Geophys. Res. 106, 33,729 (2001).

8. W. Abdalati, W., K. Steffen, J. Geophys. Res. 106, 33,983 (2001).

9. K. Steffen, S. V. Nghiem, R. Huff, G. Neumann, Geophys. Res. Lett. 31, L2040210.1029/2004GL020444 (2004).

10. W. Krabill et al., Science 289, 428 (2000).

11. W. Krabill et al., Geophys. Res. Lett. 31, L24402, doi:10.1029/2004GL021533 (2004). 
12. I. Joughin, W. Abdulati, M. Fahnestock, Nature 432, 608 (2004).

13. R. Thomas et al., J. Geophys. Res. 106, 33,707 (2001).

14. K. Khorostovsky, O. M. Johannessen, L. P. Bobylev, in Arctic Environmental Variability and Global Change, L. P. Bobylev, K. Ya. Kondratyev, O. M. Johannessen, Eds. (Springer Praxis Publ., Chichester, UK, 2003), pp. 270280.

15. J. Hurrell, Y. Kushnir, G. Ottersen, M. Visbeck (Eds.), The North Atlantic Oscillation: Climatic Significance and Environmental Impacts (American Geophysical Union, Washington, DC, 2003).

16. The NAO index used here is defined as standardized $(\sigma)$ sea-level pressure (SLP) differences between Iceland and Gibraltar [P. D. Jones, T. Jónsson, D. Wheeler, Int. J. Climatol. 17, 1433 (1997)].

17. T. Osborn, Clim. Dyn. 22, 605 (2004).

18. S. I. Kuzmina et al., Geophys. Res. Lett. 32, L04703, doi:10.1029/2004GL021064 (2005).

19. Materials and methods are provided in Supporting Online Material.

20. H. J. Zwally, A. C. Brenner, J. A. Major, R. A. Bindschadler, J. G. Marsh, Science 246, 1587 (1989).

21. D. J. Wingham, A. J. Ridout, R. Scharroo, R. Arthern, C. K. Shum, Science 282, 369 (1998).

22. P. Femenias, ERTNRS-RA-0022, May, 1997 http://earth.esa.int/pub/ESA_DOC/ QLOPR/er_tn_rs.pdf.

23. A. C. Brenner, H. J. Zwally, H. G. Cornejo, J. L. Saba, Proceedings of the ERS-ENVISAT Symposium, 16-20 October 2000, Gothenburg, Sweden (2000) and personal communication (2005).

24. R. Layberry, J. Bamber, J. Geophys. Res. 106, 33,781 (2001)

25. C. H. Davis et al., J. Geophys. Res. 106, 33,743 (2001).

26. J. Wahr, T. van Dam, K. Larson, O. Francis, J. Geophys. Res. 106, 33,755 (2001).

27. J. R. McConnell et al., Nature 406, 877 (2000).

28. D. H. Bromwich, Q. S. Chen, Y. F. Li., R. I. Cullather, J. Geophys. Res. 104, 22,103 (1999).

29. J. C. Rogers, D. J. Bathke, E. Moseley-Thompson, S.-H. Wang, Geophys. Res. Lett. 31, L212308.1029/2004GL021048 (2004).

30. P. Huybrechts, A. Letreguilly, N. Reeh, Paleogeog. Paleoclim. Paleoecol. 89, 399 (1991).

31. P. Chylek, U. Lohmann, Geophys. Res. Lett. 32, L14705 doi:10.1029/2005GL023552 (2005).

32. P. Wadhams, W. Munk, Geophys. Res. Lett. 31, L11311 doi:10.1029/2004GL020039 (2004).

33. E. Hanna et al., J. Geophys. Res. 110, D13108 10.1029/2004JD005641 (2005).

34. E. Kalnay et al., with updates, Bull. Amer. Meteor. Soc. 77, 437 (1996).
35. Supported by the Research Council of Norway through the "Marine climate and ecosystems in the seasonal ice zone (MACESIZ)" and "Mass balance and freshwater contribution of the Greenland Ice Sheet: a combined modelling and observational approach" projects; the Mohn-Sverdrup Center for Global Ocean Studies and Operational Oceanography; the International Association for the Promotion of Co-operation with Scientists from the Independent States of the Former Soviet Union (INTAS) through the Fellowship Grant for Young Scientists "Greenland Ice Sheet elevation change and variations derived from satellite altimetry" to Kirill Khvorostovsky. This study was also part of the "Climate and Environmental Change in the Arctic - CECA" project nominated for the EU Descartes Prize 2005. We also thank ESA and NASA GSFC for providing processed altimeter data, two anonymous reviewers for helpful comments, and R. J. Telford for language editing.

\section{Supporting Online Material}

www.sciencemag.org/cgi/content/full/1115356/DC1

Materials and Methods

Fig. S1

References

26 May 2005; accepted 11 October 2005

Published online 20 October 2005; 10.1126/science.1115356 Include this information when citing this paper

Fig. 1. Greenland, showing the boundaries (thick line) of the ice sheet and major ice divides (thin lines) adapted from (13). The colors indicate ice-sheet elevation change rate $(d H / d t)$ in $\mathrm{cm} /$ year (see color scale), derived from 11 years of ERS1/ERS-2 satellite altimeter data, 1992-2003, excluding some ice-sheet marginal areas (white). The spatially averaged rate is $+5.4 \pm 0.2 \mathrm{~cm} /$ year, or $\sim 5 \mathrm{~cm} /$ year when corrected for isostatic uplift. The white areas between the color-coded pixels and the thick line delimiting the ice sheet indicate no observations (see text). Latitude in ${ }^{\circ} \mathrm{N}$, longitude in ${ }^{\circ} \mathrm{W}$.

Fig. 2. Interannual variability of spatially averaged Greenland Ice Sheet elevation, shown as anomalies from the 11-year mean, 1992-2003. The data are aggregated into areas $>1500$ $\mathrm{m}$ elevation (red) and $<1500 \mathrm{~m}$ (blue), indicating divergent trends since 2000. The vertical bars indicate the standard errors of the mean $\left(\mathrm{SE}_{\mathrm{M}}\right)$ when averaging the results for each cell.

Fig. 3. Spatially averaged changes in winter Greenland Ice Sheet elevation (red) and winter NAO index (blue), lagged 1 month, 1992-2003. Winter elevation change during, e.g., 1994/1995 was determined by subtracting autumn 1994 from winter 1994/1995. For elevation, winter is defined as DJF 
with, e.g., winter 1994/1995 specified as 1995. The correlation coefficient between elevation change and the NAO index is -0.88 when lagged 1 month, e.g., NDJ for the NAO and DJF for elevation.

Fig. 4. Composite winter sea-level pressure $(\mathrm{mb})$ in Greenland and surrounding areas (A) 1994/1995 and (B) 1995/1996, which have positive and negative NAO index values, corresponding to negative and positive changes in Greenland Ice Sheet surface elevation, respectively (see Fig. 3). Data are from NCEP/NCAR Reanalysis (34).

Table 1. Spatially averaged elevation-change rates $(\mathrm{dH} / \mathrm{dt})$ and standard errors partitioned over different elevation bands of the Greenland Ice Sheet, 1992-2003, not corrected for isostatic uplift. The uncertainties $( \pm)$ in col. 2 and 3 are the standard errors of the means when averaging results within each band. The values in col. 3 are the standard error of the slope of the linear fit determined for each cell. The areas corresponding to each elevation band are indicated in col. 4 . These values exclude those cells with unreliable, discarded data (Fig. 1) (19).

\begin{tabular}{|l|l|l|l|}
\hline $\begin{array}{l}\text { Elevation } \\
\text { band (km) }\end{array}$ & $\begin{array}{l}\text { DH/dt } \\
(\mathrm{cm} / \text { year })\end{array}$ & $\begin{array}{l}\text { Standard } \\
\text { error } \\
(\mathrm{cm} / \text { year })\end{array}$ & $\begin{array}{l}\text { Area } \\
\left(\mathbf{1 0}^{3} \times\right. \\
\left.\mathbf{k m}^{2}\right)\end{array}$ \\
\hline$<1.5$ & $-2.0 \pm 0.9$ & $0.4 \pm 0.04$ & 155.1 \\
\hline $1.5-2$ & $5.6 \pm 0.5$ & $0.3 \pm 0.03$ & 228.2 \\
\hline $2-2.5$ & $7.0 \pm 0.4$ & $0.2 \pm 0.02$ & 398.9 \\
\hline $2.5-3$ & $6.4 \pm 0.3$ & $0.2 \pm 0.01$ & 458.3 \\
\hline$>3$ & $5.5 \pm 0.3$ & $0.1 \pm 0.01$ & 140.3 \\
\hline $\begin{array}{l}\text { All elevation } \\
\text { bands }\end{array}$ & $5.4 \pm 0.2$ & $0.2 \pm 0.01$ & 1380.7 \\
\hline
\end{tabular}



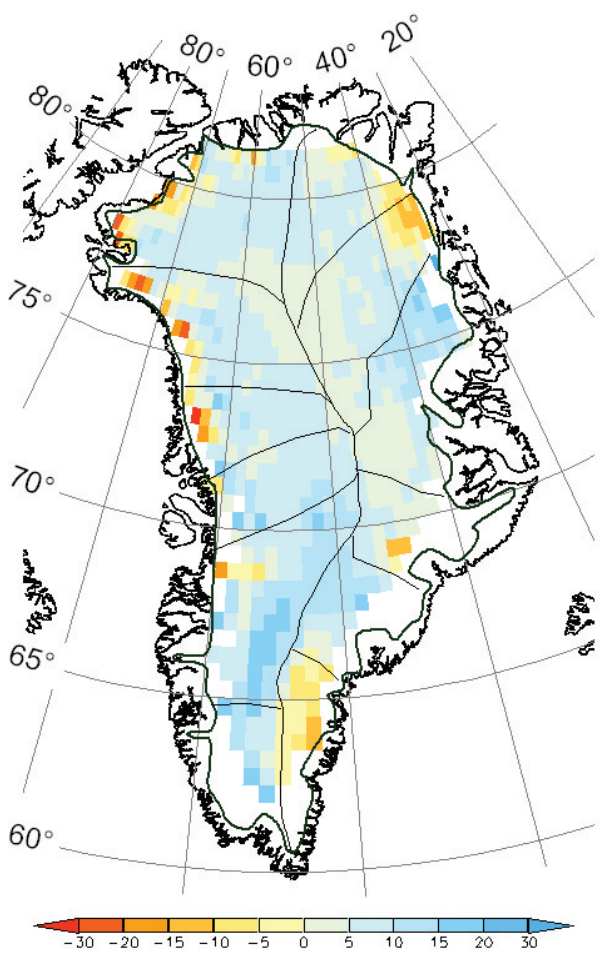


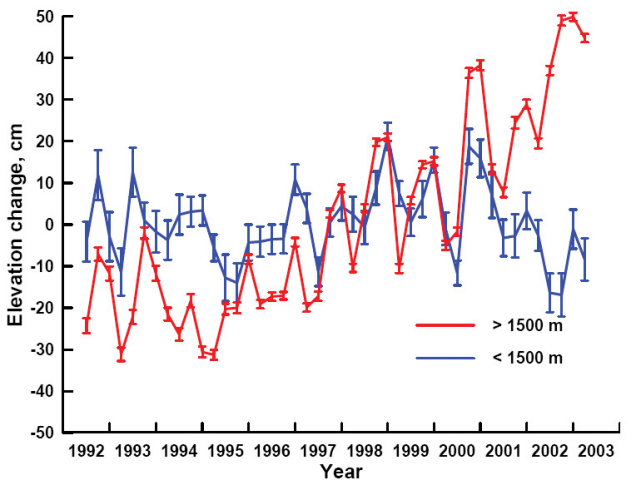




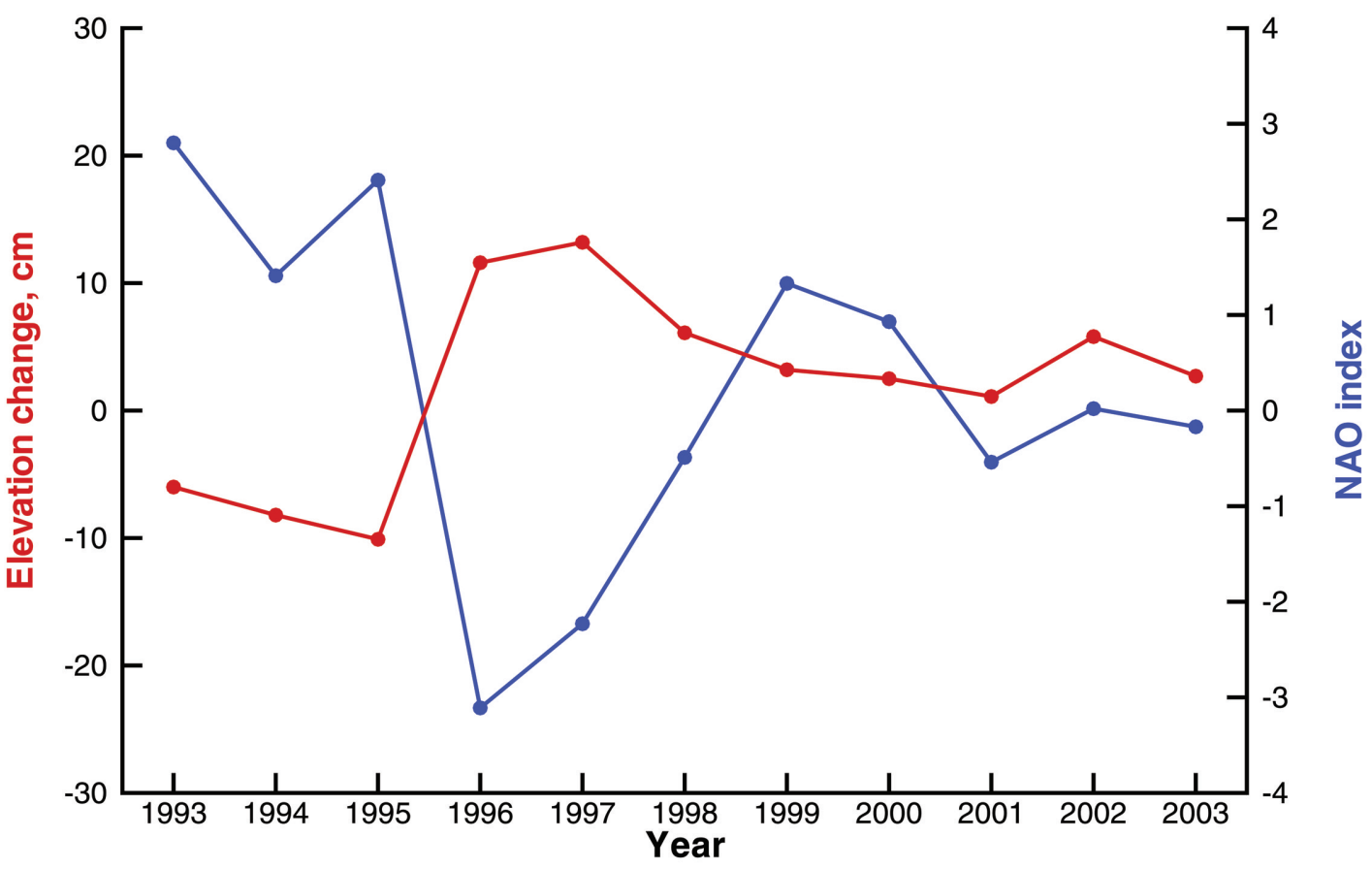


A

B

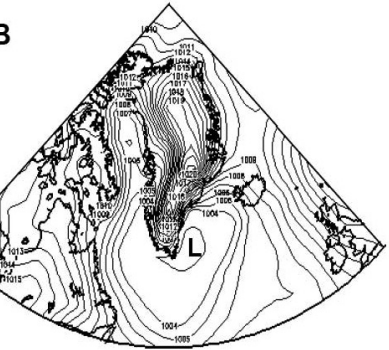

